Article

\title{
A High-Resolution Map of Emerald Ash Borer Invasion Risk for Southern Central Europe
}

\author{
Viktoria Valenta ${ }^{1}$, Dietmar Moser ${ }^{1}$, Michael Kuttner ${ }^{1}$, Johannes Peterseil ${ }^{2}$ and Franz Essl ${ }^{1, *}$ \\ 1 Division of Conservation, Vegetation and Landscape Ecology, University Vienna, Rennweg 14, \\ 1030 Vienna, Austria; E-Mails: viktoria.valenta@aon.at (V.V.); \\ dietmar.moser@univie.ac.at (D.M.); michael.kuttner@univie.ac.at (M.K.) \\ 2 Environment Agency Austria, Spittelauer Lände 5, 1090 Vienna, Austria; \\ E-Mail: johannes.peterseil@umweltbundesamt.at \\ * Author to whom correspondences should be addressed: E-Mail: franz.essl@univie.ac.at; \\ Tel.: +43-1-4277-45382 ; Fax.:+43-1-4277-9575.
}

Academic Editors: Jarmo K. Holopainen and Eric J. Jokela

Received: 2 July 2015 / Accepted: 17 August 2015 / Published: 31 August 2015

\begin{abstract}
Ash species (Fraxinus spp.) in Europe are threatened by the Emerald Ash Borer (Agrilus planipennis, EAB), an invasive wood boring beetle native to East Asia and currently spreading from European Russia westwards. Based on a high-resolution habitat distribution map (grid cell size: $25 \times 25 \mathrm{~m}$ ) and data on distribution and abundance of Common Ash (Fraxinus excelsior), the most widespread and highly susceptive host species of EAB in Europe, we assess the spatial distribution of EAB invasion risks for southern Central Europe (Austria, Switzerland, Liechtenstein, southern Germany, South Tyrol). We found highest F. excelsior abundance and thus invasion risks in extensive lowland floodplain forests, medium risks in zonal lowland forests and low risks in upper montane and subalpine forests. Based on average velocities of spread in Russia (13-31 km/year) and North America (2.5-80 km/year) from flight and human-assisted transport, EAB is likely to cover the distance $(1500 \mathrm{~km})$ between its current range edge in western Russia and the eastern border of the study region within few decades. However, secondary spread by infested wood products make earlier introductions likely. The high susceptibility and mortality of F. excelsior leave no doubt that this beetle will become a major forest pest once it reaches Central Europe. Therefore, developing and testing management approaches with the aim to halt or at least slow down the invasion of EAB in Europe have to be pursued with great urgency.
\end{abstract}


Keywords: Agrilus planipennis; alien species; EAB; forests; Fraxinus; impact; management

\section{Introduction}

Ash species (Fraxinus spp.) are widespread in temperate and subtropical zones of the northern hemisphere. Three of the 43 species of this genus are native in Europe and also occur in Central Europe: the Common Ash ( $F$. excelsior), the Narrow-leaved Ash ( $F$. angustifolia) and the Manna Ash (F. ornus) [1]. Those ash species are widespread components of mixed deciduous forests-F. excelsior throughout Europe, F. angustifolia in the South and Southeast, and F. ornus in South and South-East Europe [2]. Another ash species occurring in Europe is the American species $F$. pennsylvanica, which has been planted across Europe for timber or as ornamental tree [2,3]. This species has become a fast-spreading alien species in parts of Central Europe, in particular in floodplain forests [4].

European ash species are at risk of getting- or already are -attacked by the Emerald Ash Borer (EAB) (Agrilus planipennis Fairmaire, Coleoptera: Buprestidae) (Figure 1). This wood-boring beetle native to Asia has been introduced to North America probably in the 1990s and has had substantial impact on ecosystems and economy since then [3,5]. EAB has also been found in European Russia in 2003 (Figure 2) and is making its way westwards towards Central Europe [6] putting European forestry and environment in danger [7].

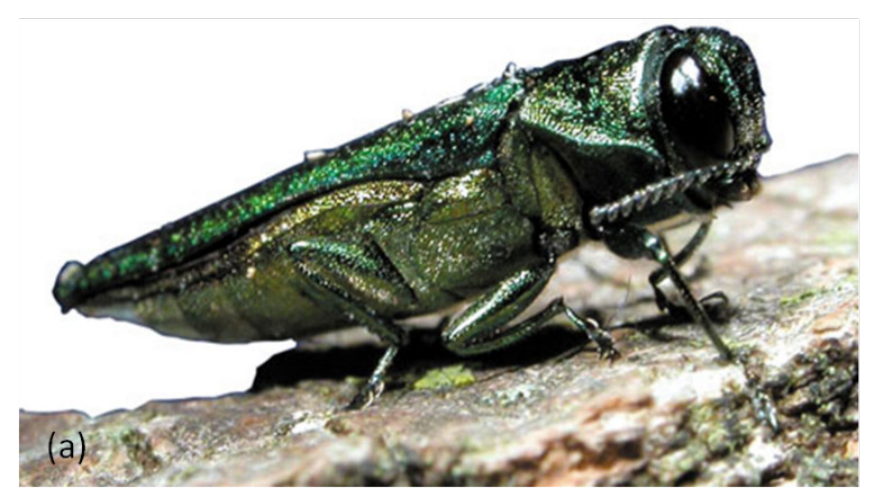

Figure 1. Pictures of adults (a) and galleries (Sources: Wikimedia Commons)

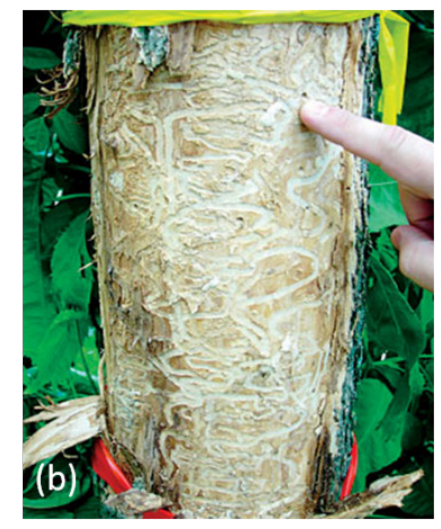

(b) of Agrilus planipennis.

Therefore, here we assess the risk of EAB invasion for the by far most widespread ash species (F. excelsior) in southern Central Europe, i.e., Austria, Switzerland, Liechtenstein, southern Germany, and South Tyrol. We use a recently compiled high-resolution habitat distribution map [8], data on ash distribution and abundance, and on the impact caused by EAB on F. excelsior in Russia, to assess the spatial distribution and scale of impacts by future EAB invasion. 


\section{Material and Methods}

\subsection{Forest Distribution Map}

We used a recently compiled high-resolution habitat distribution map with a spatial resolution of $25 \times 25 \mathrm{~m}$ [8]. This map is based on fine-scaled data from a range of data sources (e.g., habitat mapping campaigns, biotope inventories), which were harmonized and supplemented by remote mapping and modeling techniques (see [8] for details). This habitat distribution map contains two forest land cover classes (Broad Leaved Forests; Conifer Forests), which were refined by additional data from various sources in the public domain (e.g., forest inventory databases; $[9,10]$ ) to assess the distribution and abundance of $F$. excelsior. These data were harmonized and supplemented by remote mapping and modeling techniques (see [8] for details).

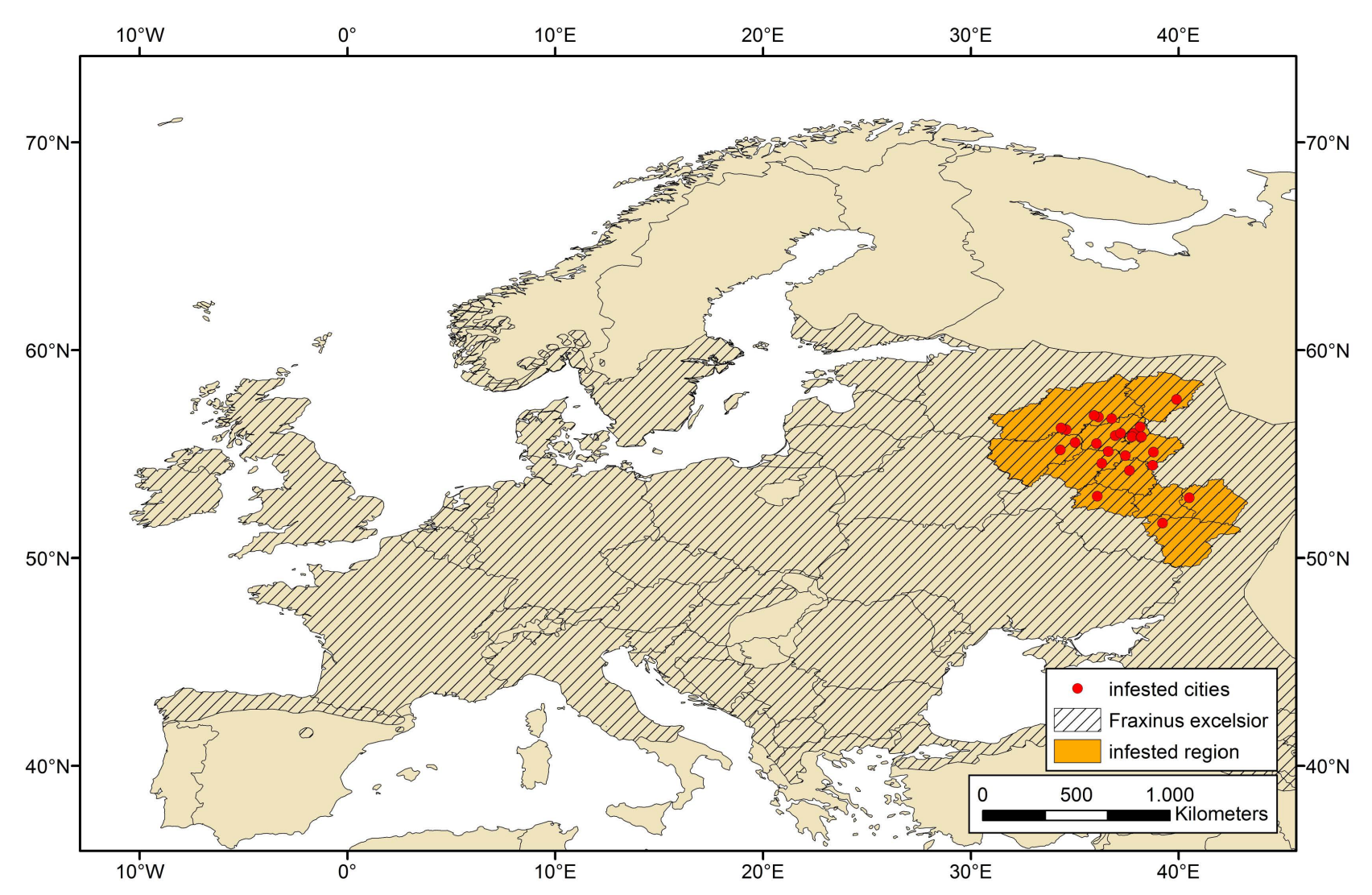

Figure 2. European range of Agrilus planipennis, showing infested regions of Russia (orange) and cities (red) where the beetle has been detected together with the distribution of Fraxinus excelsior [11]. Based on [6,12].

We note that $F$. excelsior also occurs as an important species in small landscape elements (e.g., hedgerows) in cultural landscapes and public urban spaces, which-due to their small spatial extent — are not shown in the habitat distribution map and hence excluded here. 


\subsection{Regionalizing Common Ash Distribution and Abundance}

Fraxinus excelsior is a widespread species in Central Europe which is a constant and sometimes (sub) dominant component in a range of different forest types (Supplementary Table S1). Highest constancies of occurrence are documented for floodplain forests (Alnenion glutinoso-incanae, Ulmenion, Tillio-Acerion), but also in some zonal (Fagion sylvaticae) and sub-mediterranean extrazonal forests (Quercion pubescenti-petraeae) [13]. In the Austrian Alps, forest inventory data and relevé data from the Austrian Phytosociological Database ([14], Starlinger pers. comm.) show that the species only exceptionally occurs above $1200 \mathrm{~m}$ above sea level (a.s.1.) This altitudinal distribution limit holds true across all of Austria, without any conspicuous regional differences.

Below this altitude, Austrian Forest Inventory data [15] show that $F$. excelsior abundance increases towards lower altitudes as the share of ash in deciduous forests is $\sim 2 \%(900-1200 \mathrm{~m}$ a.s. 1 .) and is $\sim 6 \%$ ( $<900 \mathrm{~m}$ a.s.1.). Hence, we applied these altitudinal thresholds by intersecting the distribution of broad leaved forests with a Digital Elevation Model (DEM) to identify forests with different abundance of F. excelsior (Table 1). In addition, as F. excelsior is a particularly abundant in floodplain forests ( $>8 \%)$, we integrated the data of the Austrian [16], German [17] and Swiss [18] floodplain inventories to delineate the distribution of floodplain forests.

Table 1. Criteria used for mapping the regional distribution of Fraxinus excelsior in the study region (Austria, Germany_-Baden-Wurttemberg (BW) and Bavaria (BAV)—Switzerland, South Tyrol).

\begin{tabular}{|c|c|c|c|c|c|}
\hline Criteria & Austria & Germany (BW/BAV) & Switzerland & South Tyrol & References \\
\hline Proportion of & & & & & [19-22], \\
\hline $\begin{array}{l}\text { Fraxinus excelsior } \\
\text { in forests }\end{array}$ & $2.7 \%$ & $4.9 \% / 1.1 \%$ & $3.4 \%$ & $<2 \%$ & $\begin{array}{c}\text { Buechsenmeister } \\
\text { pers. comm. }\end{array}$ \\
\hline \multirow{3}{*}{$\begin{array}{l}\text { Altitudinal } \\
\text { distribution }\end{array}$} & $<900: \sim 6 \%$ & $<900: \sim 6 \%$ & $<900: \sim 6 \%$ & $<900: \sim 6 \%$ & \multirow{3}{*}[15]{} \\
\hline & $900-1200: \sim 2 \%$ & $900-1200: \sim 2 \%$ & $900-1200: \sim 2 \%$ & 900-1200: 2\% & \\
\hline & $>1200: 0 \%$ & $>1200: 0 \%$ & $>1200: 0 \%$ & $>1200: 0 \%$ & \\
\hline $\begin{array}{c}\text { Distribution of } \\
\text { floodplain forests }\end{array}$ & Floodplain Inventory & Floodplain Inventory & Floodplain Inventory & Not available & [16-18] \\
\hline
\end{tabular}

\section{Results}

The distribution of broad leaved forests of different $F$. excelsior abundance is highly heterogenous on the landscape scale (Figure 3, Table 2). Highest abundances are found in extensive lowland floodplain forests along major rivers (e.g., Danube, Inn, Isar, Rhine), medium abundances are found in forests of the lowlands outside the Alps, whereas abundance in forests in the Alps is low.

The total area of broad leaved forest with $F$. excelsior occurrence in the study region-based on the second-level NUTS regions of the European Union (= sub-national socio-economic regions within Europe, [23]) - varies notably (Table 2). Forests of medium F. excelsior abundance are most wide-spread, whereas forests of high and low abundance are more restricted. 
Based on the NUTS2 regions we found that $F$. excelsior amounts to $2 \%$ of the total forest area in Austria, $1.9 \%$ in Switzerland and 1.8\% in Southern Germany (Table 2). The proportions are considerably lower in Liechtenstein (0.7\%) and South Tyrol (0.4\%).

The digital high-resolution map of $\mathrm{EAB}$ invasion risk is available on request from the authors.

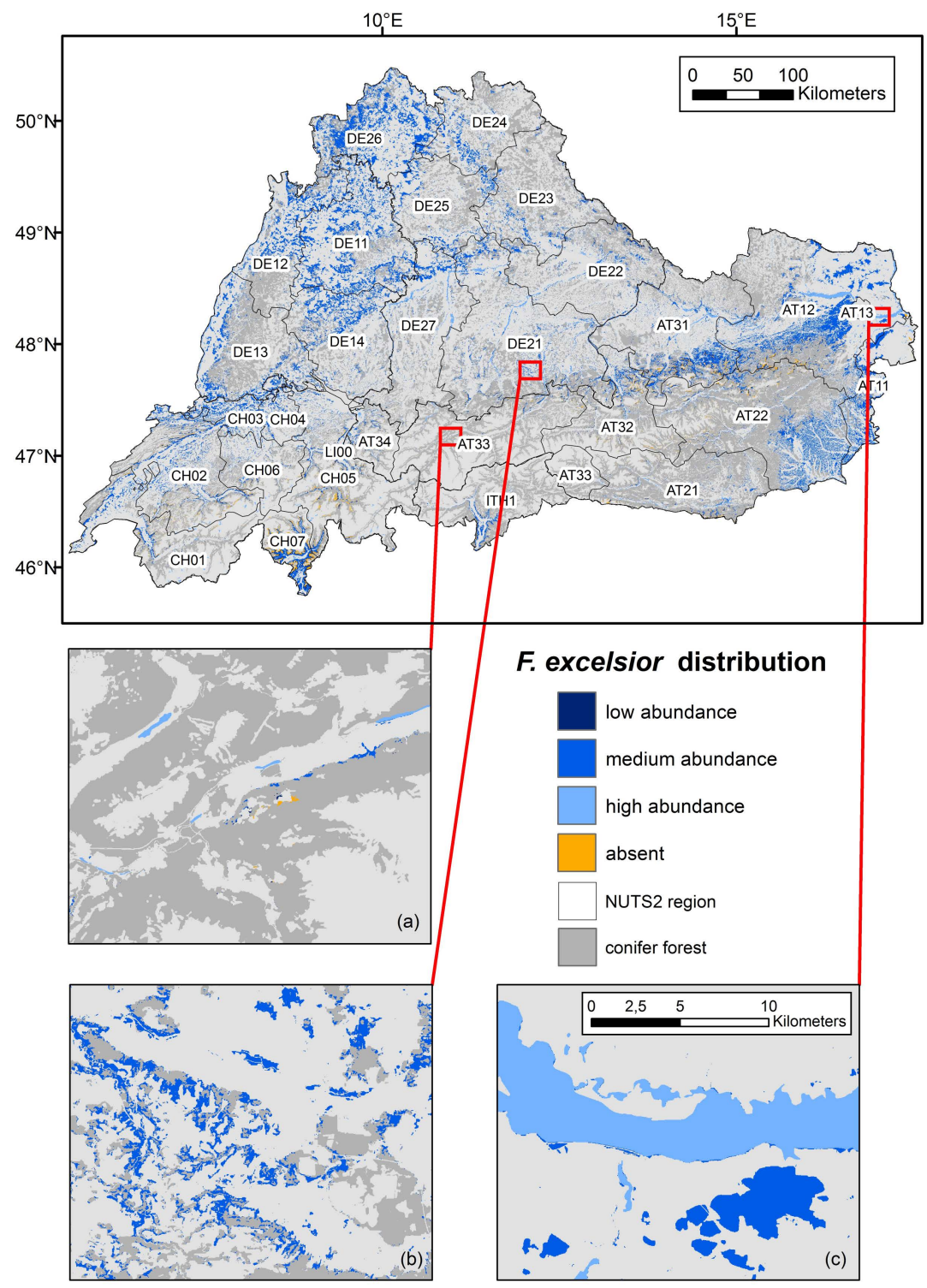

Figure 3. Risk map of future infestation by Agrilus planipennis based on F. excelsior-distribution for Austria, Bavaria, Baden-Wurttemberg, Liechtenstein, Switzerland and South Tyrol; with examples of landscapes differing in abundance of $F$. excelsior in the study region (see Table 2 for definitions): (a) mountainous landscape of the upper Inn Valley in Tyrol (near Innsbruck); (b) an agricultural landscape in the Bavarian Alpine Foothills (near Miesbach); (c) lowland floodplain forests along the Danube (east of Vienna) and adjacent remnant forests in a intensively used agricultural landscape. The acronyms and location of the NUTS2 (second-level Nomenclature of Units for Territorial Statistics) regions used in Table 2 are given. Study region: Austria (AT), Switzerland (CH), South Germany (DE), South Tyrol (ITH), and Liechtenstein (LI). 
Table 2. Forest extent and distribution of Fraxinus excelsior in the NUTS2 (second-level Nomenclature of Units for Territorial Statistics) regions in the entire study region: Austria (AT), Switzerland (CH), South Germany (DE), South Tyrol (ITH), and Liechtenstein (LI). The total area of forest, broad leaved forests (BL) and the percentage of forested area of $F$. excelsior with different levels of abundance- - low $(\sim 2 \%)$, medium ( $\sim \%)$ and high ( $\sim 10 \%)$ are given. The total extent of Fraxinus forests and the proportions of different classes of Fraxinus forests on broad-leaved forest extent are also given. See Figure 3 for location of NUTS2 regions.

\begin{tabular}{|c|c|c|c|c|c|c|c|c|c|c|c|c|}
\hline $\begin{array}{c}\text { NUTS } \\
\text { ID }\end{array}$ & NUTS Name & $\begin{array}{c}\text { Nuts Region } \\
\text { Area }\left(\mathbf{k m}^{2}\right)\end{array}$ & $\begin{array}{c}\text { Forest } \\
\text { Area }\left(\mathbf{k m}^{2}\right)\end{array}$ & $\begin{array}{l}\text { BL Forest } \\
\text { Area }\left(\mathbf{k m}^{2}\right)\end{array}$ & $\begin{array}{c}\text { Low } \\
\text { Fraxinus } \\
\text { Abundance, } \\
\text { Forest }(\sim 2 \%) \\
\left(\mathbf{k m}^{2}\right)\end{array}$ & $\begin{array}{c}\text { Medium } \\
\text { Fraxinus } \\
\text { Abundance, } \\
\text { Forest ( 6\%) } \\
\qquad\left(\mathrm{km}^{2}\right)\end{array}$ & $\begin{array}{c}\text { High Fraxinus } \\
\text { Abundance, } \\
\text { Forest }(\sim 10 \%) \\
\left(\mathbf{k m}^{2}\right)\end{array}$ & $\begin{array}{c}\text { Total } \\
\text { Fraxinus } \\
\text { Forests } \\
\left(\mathbf{k m}^{2}\right)\end{array}$ & $\begin{array}{c}\text { Proportion } \\
\text { Low } \\
\text { Abundance, } \\
\text { Fraxinus } \\
\text { Forest on BL } \\
\text { Forest Area }\end{array}$ & $\begin{array}{c}\text { Proportion } \\
\text { Medium } \\
\text { Abundance, } \\
\text { Fraxinus } \\
\text { Forest on BL } \\
\text { forest Area }\end{array}$ & $\begin{array}{l}\text { Proportion } \\
\text { High } \\
\text { Abundance } \\
\text { Fraxinus } \\
\text { Forest on BL } \\
\text { Forest Area }\end{array}$ & $\begin{array}{c}\text { Percentage } \\
\text { Fraxinus } \\
\text { Forests } \\
\text { in \% }\end{array}$ \\
\hline AT11 & Burgenland & 3944.1 & 1272.1 & 918.7 & 0.0 & 846.5 & 65.2 & 911.7 & 0 & 66.6 & 5.1 & 71.7 \\
\hline AT12 & Lower Austria & $19,184.7$ & 7971.3 & 3143.0 & 80.4 & 2544.3 & 468.5 & 3093.2 & 1.0 & 31.9 & 5.9 & 38.8 \\
\hline AT13 & Vienna & 413.4 & 90.7 & 84.6 & 0.0 & 60.3 & 24.3 & 84.6 & - & 66.5 & 26.8 & 93.2 \\
\hline AT21 & Carinthia & 9525.7 & 5363.5 & 309.2 & 56.4 & 156.5 & 63.5 & 276.4 & 1.1 & 2.9 & 1.2 & 5.2 \\
\hline AT22 & Styria & $16,436.0$ & 9748.8 & 1948.0 & 141.8 & 1627.6 & 71.7 & 1841.1 & 1.5 & 16.7 & 0.7 & 18.9 \\
\hline AT31 & Upper Austria & $11,966.4$ & 5081.6 & 1408.7 & 171.3 & 1030.3 & 133.9 & 1335.5 & 3.4 & 20.3 & 2.6 & 26.3 \\
\hline AT32 & Salzburg & 7155.5 & 3168.6 & 416.1 & 87.8 & 232.9 & 28.4 & 349.0 & 2.8 & 7.4 & 0.9 & 11.0 \\
\hline AT33 & Tyrol & $12,644.2$ & 4327.5 & 149.6 & 30.0 & 57.0 & 39.3 & 126.2 & 0.7 & 1.3 & 0.9 & 2.9 \\
\hline АТ34 & Vorarlberg & 2591.7 & 860.8 & 152.3 & 30.1 & 89.3 & 23.4 & 142.8 & 3.5 & 10.4 & 2.7 & 16.6 \\
\hline AT total & Austria & $83,861.6$ & $37,884.9$ & 8530.3 & 597.7 & 6644.7 & 918.1 & 8160.6 & 1.5 & 24.9 & 5.2 & 31.6 \\
\hline $\mathrm{CH} 01$ & Lake Geneva region & 8737.7 & 2327.5 & 481.7 & 57.9 & 323.0 & 58.0 & 438.8 & 2.5 & 13.9 & 2.5 & 18.9 \\
\hline $\mathrm{CH} 02$ & Espace Mittelland & $10,016.4$ & 3454.3 & 1034.3 & 127.1 & 767.1 & 65.2 & 959.3 & 3.7 & 22.2 & 1.9 & 27.8 \\
\hline $\mathrm{CH} 03$ & Northwestern Switzerland & 1969.2 & 692.9 & 481.3 & 2.9 & 469.2 & 9.2 & 481.3 & 0.4 & 67.7 & 1.3 & 69.5 \\
\hline $\mathrm{CH} 04$ & Zurich & 1734.1 & 484.9 & 199.2 & 1.6 & 191.8 & 5.6 & 199.1 & 0.3 & 39.6 & 1.2 & 41.1 \\
\hline $\mathrm{CH} 05$ & Eastern Switzerland & $11,524.4$ & 3483.0 & 715.4 & 124.4 & 395.1 & 70.3 & 589.8 & 3.6 & 11.3 & 2.0 & 16.9 \\
\hline $\mathrm{CH} 06$ & Central Switzerland & 4483.3 & 1324.1 & 199.4 & 26.8 & 140.7 & 17.9 & 185.4 & 2.0 & 10.6 & 1.4 & 14.0 \\
\hline $\mathrm{CH} 07$ & Ticino & 2831.6 & 1434.5 & 864.9 & 170.2 & 435.6 & 19.7 & 625.4 & 11.9 & 30.4 & 1.4 & 43.6 \\
\hline
\end{tabular}


Table 2. Cont.

\begin{tabular}{|c|c|c|c|c|c|c|c|c|c|c|c|c|}
\hline $\begin{array}{c}\text { NUTS } \\
\text { ID }\end{array}$ & NUTS Name & $\begin{array}{l}\text { Nuts Region } \\
\text { Area }\left(\mathbf{k m}^{2}\right)\end{array}$ & $\begin{array}{c}\text { Forest } \\
\text { Area }\left(\mathbf{k m}^{2}\right)\end{array}$ & $\begin{array}{l}\text { BL Forest } \\
\text { Area }\left(\mathbf{k m}^{2}\right)\end{array}$ & $\begin{array}{c}\text { Low Fraxinus } \\
\text { Abundance } \\
\text { Forest }(\sim 2 \%) \\
\quad\left(\mathrm{km}^{2}\right)\end{array}$ & $\begin{array}{c}\text { Medium } \\
\text { Fraxinus } \\
\text { Abundance } \\
\text { Forest }(\sim 6 \%) \\
\left(\mathbf{k m}^{2}\right)\end{array}$ & $\begin{array}{c}\text { High Fraxinus } \\
\text { Abundance } \\
\text { Forest }(10 \%) \\
\quad\left(\mathbf{k m}^{2}\right)\end{array}$ & $\begin{array}{c}\text { Total } \\
\text { Fraxinus } \\
\text { Forests } \\
\left(\mathbf{k m}^{2}\right)\end{array}$ & $\begin{array}{l}\text { Proportion } \\
\quad \text { Low } \\
\text { Abundance } \\
\text { Fraxinus } \\
\text { Forest on BL } \\
\text { Forest Area } \\
\end{array}$ & $\begin{array}{c}\text { Proportion } \\
\text { Medium } \\
\text { Abundance } \\
\text { Fraxinus } \\
\text { Forest on BL } \\
\text { forest Area } \\
\end{array}$ & $\begin{array}{c}\text { Proportion } \\
\text { High } \\
\text { Abundance } \\
\text { Fraxinus } \\
\text { Forest on BL } \\
\text { Forest Area } \\
\end{array}$ & $\begin{array}{c}\text { Percentage } \\
\text { Fraxinus } \\
\text { Forests } \\
\text { in } \%\end{array}$ \\
\hline $\mathrm{CH}$ total & Switzerland & $41,296.7$ & $13,201.1$ & 3976.3 & 510.9 & 2722.4 & 245.9 & 3479.2 & 3.5 & 28.0 & 1.7 & 33.1 \\
\hline DE11 & Stuttgart & $10,568.2$ & 3402.8 & 2127.0 & 0.0 & 2126.2 & 0.8 & 2127.0 & - & 62.5 & 0.0 & 62.5 \\
\hline DE12 & Karlsruhe & 6909.7 & 2948.4 & 1088.0 & 0.0 & 1004.2 & 83.8 & 1088.0 & - & 34.1 & 2.8 & 36.9 \\
\hline DE13 & Freiburg & 9493.2 & 4343.8 & 995.5 & 9.2 & 897.3 & 88.6 & 995.1 & 0.2 & 20.7 & 2.0 & 22.9 \\
\hline DE14 & Tübingen & 9093.9 & 2897.0 & 1088.8 & 16.8 & 1059.1 & 13.0 & 1088.8 & 0.6 & 36.6 & 0.5 & 37.6 \\
\hline DE21 & Oberbayern & 17538.4 & 6076.4 & 1090.8 & 45.7 & 824.0 & 209.9 & 1079.6 & 0.8 & 13.6 & 3.5 & 17.8 \\
\hline DE22 & Niederbayern & $10,332.3$ & 3551.0 & 510.2 & 44.5 & 394.5 & 65.0 & 503.9 & 1.3 & 11.1 & 1.8 & 14.2 \\
\hline DE23 & Oberpfalz & 9663.3 & 3952.5 & 384.4 & 0.6 & 382.0 & 1.7 & 384.4 & 0.0 & 9.7 & 0.0 & 9.7 \\
\hline DE24 & Oberfranken & 7224.3 & 2744.3 & 570.6 & 0.0 & 565.8 & 4.9 & 570.6 & - & 20.6 & 0.2 & 20.8 \\
\hline DE25 & Mittelfranken & 7286.6 & 2439.6 & 543.6 & 0.0 & 542.7 & 1.0 & 543.6 & - & 22.3 & 0.0 & 22.3 \\
\hline DE26 & Unterfranken & 8542.5 & 3392.0 & 2161.8 & 0.2 & 2157.6 & 4.0 & 2161.8 & 0.0 & 63.6 & 0.1 & 63.7 \\
\hline DE27 & Schwaben & $10,030.2$ & 2794.6 & 577.6 & 9.1 & 423.3 & 143.0 & 575.5 & 0.3 & 15.2 & 5.1 & 20.6 \\
\hline DE total & Germany & $106,682.6$ & $38,542.2$ & $11,138.3$ & 126.1 & $10,376.6$ & 615.5 & $11,118.2$ & 0.3 & 28.2 & 1.5 & 29.9 \\
\hline ITH1 & Bolzano & 7425.0 & 2680.5 & 225.2 & 35.8 & 178.4 & 0.0 & 214.2 & 1.3 & 6.7 & 0.0 & 8.0 \\
\hline LI00 & Liechten-stein & 163.7 & 66.9 & 8.2 & 0.5 & 7.4 & 0.1 & 7.9 & 0.7 & 11.0 & 0.1 & 11.8 \\
\hline
\end{tabular}




\section{Discussion}

\subsection{Distribution and Abundance of F. excelsior}

Fraxinus excelsior is able to grow under highly different environmental conditions, from riparian zones to mountains forests and on nutrient-rich and poor soil [24]. In addition, F. excelsior has been widely planted in cities, parks and along roads as shade or ornamental trees. Its native range in Europe is limited by cold winter temperatures, late spring frosts and dry, hot summers [1,3]. Common Ash has an intermediate status between pioneer species and old-growth forest components. It usually occurs in groups within broad leaved forests, is often a dominant species in juvenile forest stands, but rarely attains dominance in older forest stages [1,24].

In southern Central Europe, F. excelsior occurs in a range of habitats and thus it is the 4th most common broadleaved tree species ([25], Büchsenmeister pers. comm.). We found that $F$. excelsior amounts to $1.8 \%-2.0 \%$ of the total forest area in Austria, Switzerland and Southern Germany, while proportions are considerably lower in the smaller regions Liechtenstein $(0.7 \%)$ and South Tyrol $(0.4 \%)$. However, recent forest inventory data report somewhat higher proportions of $F$. excelsior, maybe due to differing inventory methods: It is assumed that the proportion of F. excelsior in Austria is ca. 2.7\% of all forest trees, 3.4\% in Switzerland, 4.9\% in Baden-Wurttemberg and 1.1\% in Bavaria [19-21]. No data are available for South Tyrol and Liechtenstein.

\subsection{EAB Invasion Risks into Central Europe}

The spread of $A$. planipennis is facilitated by two spread mechanisms-i.e., endogenous spread (by flight) and human-assisted transportation [7]. Whereas the first mechanism is most relevant for short-range dispersal and range-infilling, the second one is particularly so for long-distance dispersal. Given observed average velocities of spread in Russia (13-31 km year ${ }^{-1}$ ) and North America $\left(2.5-80 \mathrm{~km} \mathrm{year}^{-1}\right)$ [7], it is likely that EAB will cover the distance $(1500 \mathrm{~km})$ between its current range edge in western Russia and the eastern border of the study region within a few decades. In addition, spread of EAB in the study region will be facilitated by the rather continuous distribution of $F$. excelsior. In the study region, potential corridors for spread can be found particularly along rivers and more generally in the lowlands (Figure 2), while the higher elevations of the Alps may serve as a barrier slowing or halting regional spread. Given the high connectivity of occurrences of $F$. excelsior in low and medium altitudes, it seems unlikely that the availability of host trees will be a major factor for limiting spread outside the Alps.

Human-assisted secondary long-range dispersal is most likely with infested wood and wood products. Although import restrictions of ash wood products from infested regions into the European Union have been introduced (e.g., [26,27]), secondary spread (e.g., by infested wood products) into Central Europe is increasingly likely to occur, the larger the infested area in Eastern Europe becomes. Thus, introduction into Central Europe may occur at any time. Invasion history shows that ports and trade centers are main gateways for such accidental introductions of alien species through international trade [28]. As EAB is able to cope with wide range of climatic condition [29,30], it is likely that it will be able to colonize the full range of $F$. excelsior-habitats in Central Europe. 
We note that although the results of this study are not based on modeling the spread of EAB using habitat characteristics and the species' ecological needs as has been done for North America [31,32], our study is the first one which provides a spatially explicit analyses of the invasion risks posed by EAB into a European region. Due to the high-resolution habitat distribution map [8] as the foundation of our analyses, we were able to regionalize invasion risks to a high extent. This information provides a basis for quantifying the scale of the likely impacts caused by EAB, and it identifies likely corridors of spread once EAB spreads into the study region

\section{Conclusions}

The high susceptibility and mortality of F. excelsior to infestations of EAB in Russia [7] leave no doubt that this beetle will become a major forest pest once it reaches Central Europe. This will put additional pressure on $F$. excelsior, which is also suffering from a fungal disease for several years, leading to wide spread ash dieback [24].

Although experience from the spread of EAB in North America has shown that halting its spread is difficult (reviewed by [7]), developing and testing management approaches with the aim to halt or at least slow down the invasion of EAB in Europe must be pursued with great urgency. Therefore, Central European countries not yet infested should develop dedicated precautionary measures to prevent inadvertent import of EAB into their territory. Additional education campaigns will help to raise awareness of the potential risk of $A$. planipennis invasions with the wider public, forest managers, and also in the scientific community.

\section{Acknowledgments}

We are grateful to Richard Büchsenmeister, Franz Starlinger and Wolfgang Willner for information on the distribution of Fraxinus excelsior. Jessica Wiesinger and Thomas Ehlert provided the data on the distribution of floodplain forests in southern Germany. The comments of two anonymous reviewers are highly appreciated.

\section{Author Contributions}

V.V., F.E. and D.M. led the analyses and writing. M.K. and J.P. contributed land cover data, discussed the results and commented on the manuscript.

\section{Conflicts of Interest}

The authors declare no conflict of interest. 


\section{References}

1. FRAXIGEN. Ash Species in Europe: Biological Characteristics and Practical Guidelines for Sustainable Use; Oxford Forestry Institute, University of Oxford: Oxford, UK, 2015; p. 128.

2. EPPO. Data Sheet Agrilus planipennis. Bull. OEPP/EPPO Bull. 2005, 35, 436-438.

3. Baranchikov, Y.; Mozolevskayam, E.; Yurchenko, G.; Kenis, M. Occurrence of the Emerald Ash Borer, Agrilus planipennis in Russia and its potential impact on European forestry. EPPO Bull. 2008, 38, 233-238.

4. Schmiedel, D.; Tackenberg, O. Hydrochory and water induced germination enhance invasion of Fraxinus pennsylvanica. Forest Ecol. Manag. 2014, 304, 437-443.

5. Kovacs, K.F.; Haight, R.G.; McCullough, D.G.; Mercader, R.J.; Siegert, N.W.; Liebhold, A.M. Cost of potential Emerald Ash Borer damage in U.S. communities, 2009-2019. Ecol. Econ. 2010, 69, 569-578.

6. Orlova-Bienkowskaja, M.J. Ashes in Europe are in danger: The invasive range of Agrilus planipennis in European Russia is expanding. Biol. Invasions 2013, 16, 1345-1349.

7. Valenta, V.; Moser, D.; Essl, F. A new forest pathogen in Europe: A review of the biology, ecology, and impacts caused by the Emerald Ash Borer (Agrilus planipennis). Biod. Conserv. 2015, submitted.

8. Kuttner, M.; Essl, F.; Peterseil, J.; Dullinger, S.; Rabitsch, W.; Schindler, S.; Hülber, K.; Gattringer, A.; Moser, D. A new high-resolution habitat distribution map for Austria, Liechtenstein, southern Germany, South Tyrol and Switzerland. Eco.Mont 2015, 7, doi:10.1553/eco.mont-7-2s18.

9. Kempeneers, P.; Sedano, F.; Seebach, L.; Strobl, P.; San-Miguel-Ayanz, J. Data Fusion of Different Spatial Resolution Remote Sensing Images Applied to Forest-Type Mapping. IEEE Trans. Geosci. Remote Sens. 2011, 49, 4977-4986.

10. Bauerhansl, C.; Koukal, T.; Schadauer, K. Erste österreichweite Waldkarte basierend auf der Österreichischen Waldinventur. Available online: http://www.waldwissen.net/themen/ inventur_monitoring/fernerkundung/bfw_waldlayer_2008_DE. 02.01 .2008 (accessed on 08 December 2014).

11. EUFORGEN. Distribution map of Common Ash (Fraxinus excelsior). EUFORGEN Secretariat: Rome, Italy. Available online: http://www.euforgen.org (accessed on 08 December 2014).

12. Straw, N.A.; Williams, D.T.; Kulinich, O.; Gninenko, Y.I. Distribution, impact and rate of spread of Emerald Ash Borer Agrilus planipennis (Coleoptera: Buprestidae) in the Moscow region of Russia. Forestry 2013, 86, 515-522.

13. Die Wälder und Gebüsche Österreichs. Ein Bestimmungswerk mit Tabellen; Willner, W., Grabherr, G., Eds.; Spektrum Akademischer Verlag: Heidelberg, Germany, 2007.

14. Willner, W.; Berg, C.; Heiselmayer, P. Austrian Vegetation Database. Biod. Ecol. 2012, 4, 333.

15. Schadauer, K. Baumartenatlas für Österreich: Die Verbreitung der Baumarten nach Daten der Oesterreichischen Waldinventur. In FBVA-Berichte; Forstl. Bundesversuchsanst, Waldforschungszentrum: Vienna, Austria, 1994; Volume 76, p. 126.

16. Lazwoski, W.; Schwarz, U.; Essl, F.; Götzl, M.; Peterseil, J.; Egger, G. Aueninventar Österreich; Final Report; BMLFUW: Vienna, Austria, 2011. 
17. Brunotte, E.; Dister, E.; Günther-Diringer, D.; Kuenzen, U.; Mehl, D. Flussauen in Deutschland: Erfassung und Bewertung des Auenzustandes. In Naturschutz und Biologische Vielfalt; BfN-Schriftenvertrieb im Landwirtschaftsverl: Bonn, Germany, 2010; Volume 87, p. 244.

18. BAFU. Bundesinventar der Auengebiete von nationaler Bedeutung. GIS-Daten Biodiversität. Bundesamt für Umwelt. 2014. Available online: http://www.bafu.admin.ch/gis/02911/07403/ index.html?lang=de (accessed on 24 July 2014).

19. Bonde, A. Stellungnahme des Ministeriums für Ländlichen Raum und Verbraucherschutz zu Eschensterben in Deutschland und Baden-Württemberg. In Drucksache 15/5503, 16.07.2014; Landtag von Baden-Württemberg: Stuttgart, Germany, 2014.

20. Schweizerisches Landesforstinventar: Ergebnisse der dritten Erhebung 2004-2006; Brändli, U.B., Ed.; Eidgenössische Forschungsanstalt für Wald, Schnee und Landschaft WSL: Birmensdorf, Switzerland, 2010; p. 312.

21. Immler, T. Die Esche im Staatswald der Forstdirektion Oberbayern-Schwaben. In Beiträge zur Esche-Fachtagung zum Baum des Jahres 2001. LWF-Wissen 34; Bayerische Landesanstalt für Wald und Forstwirtschaft (LWF): München, Germany, 2002.

22. Autonome Provinz Bozen-Südtirol. Abteilung Forstwirtschaft Abteilung Forstwirtschaft: Die Hauptbaumarten Südtirols. 2014. Available online: http://www.provinz.bz.it/forst/ wald-holz-almen/1846.asp (accessed on 8 December 2014).

23. Eurostat. Available online: http://ec.europa.eu/eurostat/web/nuts/overview (accessed on 9 December 2014).

24. Pautasso, M.; Ass, G.; Queloz, V.; Holdenrieder, O. European ash (Fraxinus excelsior) diebackA conservation biology challenge. Biol. Conserv. 2013, 158, 37-49.

25. Hauk, E. Bäume und Sträucher-Ihre Verbreitung. Beilage zur Österreichischen Forstzeitung 12/1997. Available online: https://bfw.ac.at/inst7/publ/oefz12-97/hauk.html (accessed on 8 December 2014).

26. EFSA. Statement on a heat treatment to control Agrilus planipennis. Eur. Food Saf. Auth. J. 2012. Available online: http://www.efsa.europa.eu/en/efsajournal/doc/2646.pdf. (accessed on 19 November 2014).

27. Forestry Commission. Importing Wood, Wood Products and Bark, 2nd ed.; Forestry Commission: Edinburgh, UK. Available online: http://www.forestry.gov.uk/pdf/FCPH001.pdf/\$FILE/ FCPH001.pdf (accessed on 15 November 2014).

28. Banks, N.C.; Paini, D.R.; Bayliss, K.L.; Hoddda, M. The role of global trade and transport network topology in the human-mediated dispersal of alien species. Ecol. Lett. 2014, 18, 188-199.

29. Crosthwaite, J.C.; Crosthwaite, J.C.; Sobek, S.; Lyons, D.B.; Bernards, M.A.; Sinclair, B.J. The overwintering physiology of the Emerald Ash Borer, Agrilus planipennis Fairmaire (Coleoptera: Buprestidae). J. Insect Phys. 2011, 57, 166-173.

30. Sobek, S.; Rajamohan, A.; Dillon, D.; Cumming, R.C.; Sinclair, B.J. High temperature tolerance and thermal plasticity in Emerald Ash Borer Agrilus planipennis. Agric. Forest Entomol. 2011, 13, 333-340.

31. Muirhead, J.R.; Leung, B.; van Overdijk, C.; Kelly, D.W.; Nandakumar, K.; Marchant, K.R.; MacIsaac, H.J. Modelling local and long-distance dispersal of invasive Emerald Ash Borer Agrilus planipennis (Coleoptera) in North America. Divers. Distrib. 2006, 12, 71-79. 
32. Prasad, A.M.; Iverson, M.R.; Peters, M.P.; Bossenbroek, J.M.; Matthews, S.N.; Syndor, T.D.; Schwartz, M.W. Modeling the invasive Emerald Ash Borer risk of spread using a spatially explicit cellular model. Landsc. Ecol. 2010, 25, 353-369.

33. Essl, F.; Egger, G. Lebensraumvielfalt in Österreich; Environment Agency: Vienna, Austria, 2010.

(C) 2015 by the authors; licensee MDPI, Basel, Switzerland. This article is an open access article distributed under the terms and conditions of the Creative Commons Attribution license (http://creativecommons.org/licenses/by/4.0/). 